\title{
KETERPAKAIAN KONSEP HUKUM BERNOULLI DAN DESAIN EKSPERIMENNYA DI DALAM FISIKA TERAPAN PRODI REKAYASA POLBAN
}

\author{
I Gede Rasagama $^{1, a)}$, Ratu Fenny Muldiani ${ }^{2, b)}$, Kunlestiowati Hadiningrum ${ }^{3, c)}$ \\ ${ }^{1,2,3}$ Politeknik Negeri Bandung, Jl Gegerkalong Hilir, Ds Ciwaruga, Bandung, 40012
}

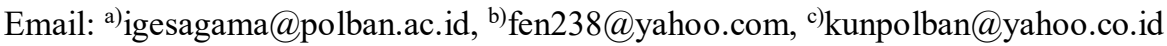

\begin{abstract}
Abstrak
Penelitian bertujuan untuk mengetahui keterpakaian konsep Hukum Bernoulli dan desain eksperimennya dalam Mata Kuliah Dasar Keahlian (MKDK) Fisika Terapan di Politeknik. Tempat penelitian di POLBAN. Studi diawali dengan mengkaji silabus MKDK Fisika Terapan dan Mata Kuliah Keahlian (MKK) Prodi di Jurusan Rekayasa, yang mendapat MKDK Fisika Terapan. Dilanjutkan kuesioner ke dosen pengampu MKK prodi yaitu 3 DIII dan 3 DIV. Untuk memperdalam isi kuesioner, dilakukan interview ke narasumber. Data dianalisis untuk mengukur: keterpakaian konsep Hukum Bernoulli dalam silabus MKDK Fisika Terapan dan MKK Prodi, pendapat dosen MKK prodi prihal kebutuhan konsep Hukum Bernoulli dalam MKDK Fisika Terapan, perlunya pendalaman melalui eksperimen, dan karakteristik desain eksperimen yang diharapkan. Hasil studi menunjukkan 11 prodi dari 24 prodi yang ada di jurusan Rekayasa, memasukkan konsep Hukum Bernoulli dalam silabus MKDK Fisika Terapan, semua subjek penelitian memasukkan konsep Hukum Bernoulli dalam silabus salah satu MKKnya, semua narasumber berpendapat perlu diajarkan konsep Hukum Bernoulli dalam MKDK Fisika Terapan, dan 67\% narasumber berpendapat perlu pendalaman melalui eksperimen. Karakteristik desain eksperimen yang diharapkan adalah mampu men-create kompetensi mahasiswa dalam mengukur laju dan tekanan zat alir dalam pipa berbagai ukuran. Pendekatan ideal, syarat, dan batas keberlakuan Hukum Bernoulli dapat dijadikan dasar desain eksperimen. Tampak bahwa keterpakaian konsep Hukum Bernoulli bagi mahasiswa dan institusi politeknik adalah tinggi
\end{abstract}

Kata-kata kunci: Hukum Bernoulli, desain eksperimen, fisika terapan mahasiswa politeknik

\begin{abstract}
The study aim is to determine the usefulness of the concept and design of experiments Bernoulli's Law in Proficiency Basic Courses (PBC) of Applied Physics at the Polytechnic. The place of research is in POLBAN. The study begins review of PBC syllabus of Applied Physics and Prodi Proficiency Courses (PPC) syllabus at the Department of Engineering, who gets service PBC of Applied Physics. Continued with questionnaire to lecturers PPC is 3 DIII and 3 DIV. To deepen the contents of the questionnaire, we conducted interviews to informants. Data were analyzed to measure: usefulness of Bernoulli's Law concepts in the PBC of applied physics and PPC syllabus, PPC lecturer opinion about needs of Bernoulli's Law concept in PBC of Applied Physics, the necessity of deepening through experiments and experimental design characteristics. The study results showed 11 prodi of 24 prodi in engineering majors, inserts the concept of Bernoulli's Law into the applied physics syllabus, all research subjects insert the concept of Bernoulli's Law in the one of PPC syllabus, overall interviewees believe it is needed to be taught the concept of Bernoulli's Law in PBC of Applied Physics, and 67\% informants believe it is necessary for deepening through experimentation. Characteristic of the expected experimental design is capable of generating student competence in measuring the speed and pressure of the flow in the pipes of various sizes. The ideal approach, requirement, and limits of the enforceability of Bernoulli's Law can be used as the basis of design of experiments. It appears that the usefulness category of Bernoulli's Law concept for students and polytechnic institutions is high
\end{abstract}

Keywords: Bernoulli's Law, experimental design, polytechnics students applied physics. 


\section{Pendahuluan}

Hukum Bernoulli merupakan sebuah konsep besar, hasil penggabungan beberapa unit konsep fisika seperti tekanan, massa jenis, laju zat alir, kekentalan zat alir, dan ketinggian potensial gravitasi. Kapasitas konsep ini mampu mendeskripsikan secara kualitatif dan kuantitatif prilaku dinamis zat alir (cair dan gas) dalam ruang ataupun saluran berdinding padatan seperti pipa. Banyak cara kerja peralatan teknik di dunia industri dilandasi oleh penerapan konsep ini seperti sayap pesawat terbang, cerobong asap, penyemprot racun serangga, tabung pitot, tabung venturi, karburator, kapal layar, tangki bocor, dan lain sebagainya. Disisi lain, analisis prilaku dinamis zat alir sangat masif dijumpai dalam peralatan teknik untuk kegiatan produksi di industri seperti prilaku bahan bakar mesin selama mengalami perubahan bentuk ke bentuk yang lain, prilaku air untuk pertukaran kalor selama proses pendinginan mesin industri karena kondisi overheat (kalor berlebihan) selama proses produksi, dan lain sebagainya. Oleh karena keterpakaian konsep ini di bidang industri atau rekayasa sangat luas maka konsep ini sangat perlu dan penting dipelajari, baik melalui pembelajaran di ruang kelas (teori) maupun di ruang laboratorium (melalui praktek) berupa kegiatan eksperimen.

Menurut Sudirman [1], metode eksperimen adalah cara penyajian pelajaran, dimana mahasiswa melakukan percobaan dengan mengalami dan membuktikan sendiri sesuatu yang dipelajari. Menurut M. Ali [2], metode eksperimen adalah percobaan tentang sesuatu. Dalam hal ini setiap mahasiswa bekerja sendiri-sendiri. Pelaksanaan eksperimen lebih memperjelas hasil belajar, karena setiap mahasiswa mengalami dan melakukan kegiatan percobaan. Menurut Nana Sudjana [3], metode eksperimen adalah metode mengajar yang sangat efektif sebab membantu mahasiswa untuk mencari jawaban dengan usaha sendiri berdasarkan fakta (data) yang benar. Dengan demikian metode eksperimen dapat dipandang sebagai suatu cara penyampaian pengajaran dengan melakukan percobaan untuk menemukan sendiri apa yang dipelajari baik secara individu dan kelompok sehingga mahasiswa mampu mengecek kebenaran hipotesis atau membuktikan sendiri yang dipelajari.

Di sisi lain tuntutan kemampuan kerja lulusan pendidikan politeknik sesuai deskripsi KKNI adalah mampu menyelesaikan pekerjaan berlingkup luas dengan memilih berbagai metode untuk program DIII, dan mampu mengaplikasikan, mengkaji, membuat desain, memanfaatkan IPTEKS dalam menyelesaikan masalah untuk program DIV. Hasil kajian mnunjukkan bahwa metode eksperimen dalam pembelajaran fisika merupakan salah satu alternatif solusi untuk memecahkan masalah yang dihadapi mahasiswa. Metode ini mampu membuka cakrawala mahasiswa untuk berargumentasi dan membuktikan hipotesis yang telah dipelajari sehingga pembelajarannya menjadi lebih berpusat pada mahasiswa bukan pada dosen (teacher centered). Kegiatan eksperimen lebih menekankan pada kinerja proses dan kinerja produk (performance test). Melalui metode eksperimen, mahasiswa diberi ruang bagi terbentuknya ketrampilan untuk menemukan fakta-fakta ilmiah melalui percobaan yaitu mengalami atau melakukan sendiri, mengikuti suatu proses, mengamati suatu obyek, menganalisis, membuktikan, dan menarik kesimpulan sendiri mengenai obyek, keadaan atau suatu proses. Oleh karena itu keterampilan berpikir yang dibangkitkan oleh metode eksperimen sangat menunjang bagi tercapainya KKNI tersebut. Penerapan metode eksperimen sangatlah cocok untuk pendidikan politeknik dalam kerangka untuk mencapai KKNI tersebut,

Untuk keberhasilan implementasi metode eksperimen sebagai aktivitas pembelajaran di laboratorium amatlah dibutuhkan suatu desain eksperimen yang efisien dan efektif prihal eksperimen Hukum Bernoulli tersebut. Ukuran efisien dan efektif tersebut dilihat berdasarkan kuantitas dan kualitas bahan baku, kapasitas proses kegiatan yang harus dilaksanakan, serta kandungan konsep fisika yang terkandung di dalam desain eksperimen yang ditetapkan. Efisien artinya jumlah bahan baku tidak membutuhkan biaya mahal namun memenuhi capaian pembelajaran yang diharapkan meliputi jumlah konsep (kognitif) yang disasar, dampak prilaku (afektif) dalam personal mahasiswa, dan keterampilan (skill) yang dicreate oleh implementasi desain eksperimen tersebut. Efektif artinya desain eksperimen mengandung serangkaian proses kegiatan yang akurat, presisi, valid, dan realibel terhadap sasaran atau tujuan pembelajaran. Desain eksperimen ini juga harus ditunjang dengan modul praktikum yang mudah digunakan, dipahami oleh mahasiswa dan cepat mengarahkan kegiatan bagi tercapainya tujuan pembelajaran. Sesuai karakteristik metode pembelajaran eksperimen maka desain eksperimen harus mengandung variabel-variabel yang diidentifikasi, meliputi variabel manipulasi, variabel respon, dan variabel kontrol. Untuk itu dalam penelitian ini, akan dtelusuri dan dikaji "keterpakaian konsep Hukum Bernoulli dan desain eksperimen Hukum Bernoulli”.

\section{Metode Penelitian}

Penelitian memakai metode deskriptif analitik. Dokumen yang dianalisis berupa silabus MKDK Fisika Terapan, silabus MKK prodi, hasil kuesioner dan hasil wawancara dengan para dosen MKK Prodi DIII dan DIV Jurusan Rekayasa POLBAN. Dokumen memberi petunjuk pentingnya konsep Hukum Bernoulli bagi pendidikan politeknik dan narasumber sangat paham prihal keterpakaian konsep Hukum Bernoulli dan 
kapasitas desain eksperimen untuk konsep Hukum Bernoulli.

Instrumen penelitian meliputi formulir untuk perumusan keterpakaian konsep berbasis silabus MKDK Fisika Terapan, keterpakaian konsep berbasis silabus MKK, kuesioner dan wawancara untuk dosen selaku narasumber.

Analisis data (kualitatif) dilakukan dengan melihat kecenderungan yang ditunjukkan oleh data prihal keterpakaian konsep Hukum Bernoulli dan desain eksperimennya, yang digali dari narasumber.

Alur penelitian dibagi dalam tahapan sbb:

a) Studi pendahuluan berupa studi dokumen silabus MKDK Fisika Terapan dan MKK Prodi terkait prihal keterpakaian konsep Hukum Benoulli bagi prodi di Jurusan Rekayasa POLBAN.

b) Perancangan instrumen yaitu formulir kajian keterpakaian konsep Hukum Bernoulli dalam silabus MKDK Fisika Terapan dan MKK sejumlah prodi, formulir kuesioner dan wawancara ke dosen MKK prihal keterpakaian konsep dan desain eksperimen Hukum Bernoulli bagi prodi di Jurusan Rekayasa POLBAN. c) Implementasi instrumen untuk inventarisasi data hasil studi dokumen silabus MKDK Fisika Terapan dan MKK Prodi, isian kuesioner, dan wawancara dosen-dosen MKK Prodi di Jurusan Rekayasa POLBAN.

d) Analisis data, yaitu menganalisis kecenderungan data yang terjadi dan melaksanakan triangulasi data, hasil penerapan instrumen penelitian.

e) Simpulan, yaitu menyimpulkan keterpakaian konsep dan desain eksperimennya berdasarkan hasil analisa data yang telah dilakukan.

\section{Hasil dan Pembahasan}

Bedasarkan metode penelitian pada tahap implementasi instrumen berupa studi dokumen silabus secara kuantitatif diperoleh hasil sekitar 11 prodi dari 24 prodi yang ada di Jurusan Rekayasa, memasukkan konsep Hukum Bernoulli dalam Mata Kuliah Dasar Keahlian Fisika Terapan. Prodi tersebut antara lain ditunjukkan pada Tabel 1 berikut:

Tabel 1. Hasil Studi Dokumen Silabus

\begin{tabular}{|c|l|l|c|}
\hline No & \multicolumn{1}{|c|}{ Jurusan } & \multicolumn{1}{|c|}{ Program studi } & Diploma \\
\hline 1 & Teknik Mesin & Teknik Mesin & III \\
\hline 2 & Teknik Mesin & Teknik Perancangan \& Konstruksi Mesin & IV \\
\hline 3 & Teknik Mesin & Teknik Proses Manufaktur & IV \\
\hline 4 & Teknik Mesin & Teknik Aeronautika & III \\
\hline 5 & Teknik Konversi Energi & Teknik Konversi Energi & III \\
\hline 6 & Teknik Konversi Energi & Teknik Pembangkit Tenaga Listrik & IV \\
\hline 7 & Teknik Konversi Energi & Teknik Konservasi Energi & IV \\
\hline 8 & Teknik Refrigerasi \& Tata Udara & Teknik Refrigerasi \& Tata Udara & III \\
\hline 9 & Teknik Refrigerasi \& Tata Udara & Teknik Refrigerasi \& Tata Udara & IV \\
\hline 10 & Teknik Kimia & Teknik Kimia & III \\
\hline 11 & Teknik Kimia & Teknik Kimia Produksi Bersih & IV \\
\hline
\end{tabular}

Dari sudut pandang prihal utilitas konsep tampak bahwa bidang kajian konsep Hukum Bernoulli ini khususnya bagi Jurusan Rekayasa di POLBAN sangatlah penting. Hal ini dikuatkan juga dengan hasil penelitian pada tahap selanjutnya, yaitu hasil kuesioner dan wawancara pada 3 dosen MKK Prodi DIII dan 3 dosen MKK Prodi DIV di Jurusan Rekayasa POLBAN, yang mendapat layanan MKDK Fisika Terapan.
Berdasarkan data kuesioner dan wawancara diperoleh hasil bahwa keseluruhan narasumber berpendapat konsep Hukum Bernoulli perlu diajarkan dalam MKDK Fisika Terapan. Konsep ini sangat penting untuk menunjang beberapa mata kuliah yang ada di program studi.

Eksperimen Hukum Bernoulli selanjutnya didesain berdasarkan kebutuhan prodi. Gambaran kebutuhan prodi seperti ditunjukkan oleh Tabel 2. 
Tabel 2. Analisis kebutuhan prodi terhadap eksperimen Hukum Bernoulli dan desain eksperimennya

\begin{tabular}{|c|c|c|c|c|c|}
\hline No & $\begin{array}{c}\text { Asal prodi } \\
\text { narasumber }\end{array}$ & $\begin{array}{c}\text { Mata kuliah } \\
\text { terkait }\end{array}$ & $\begin{array}{c}\text { Contoh aplikasi Hukum Bernoulli di } \\
\text { prodi }\end{array}$ & $\begin{array}{r}\text { Kebutuhan } \\
\text { eksperimen }\end{array}$ & $\begin{array}{c}\text { Desain } \\
\text { eksperimen }\end{array}$ \\
\hline 1 & $\begin{array}{l}\text { D4 Teknik } \\
\text { Konsevasi } \\
\text { Energi } \\
\text { D4 Teknik } \\
\text { Pembangkit } \\
\text { Tenaga } \\
\text { Listrik }\end{array}$ & $\begin{array}{l}\text { Mekanika } \\
\text { Fluida }\end{array}$ & $\begin{array}{l}\text { Penerapan Hukum Bernoulli } \\
\text { diantaranya pada mesin fluida. Mesin } \\
\text { fluida adalah mesin yang berfungsi } \\
\text { untuk merubah energi mekanik menjadi } \\
\text { energi potensial dan sebaliknya, } \\
\text { merubah energi mekanik dalam bentuk } \\
\text { fluida. Contoh mesin fluida adalah } \\
\text { pompa, blower, compressor, turbin air, } \\
\text { turbin uap, kincir angin, dllnya. }\end{array}$ & $\begin{array}{l}\text { Membutuhkan } \\
\text { pendalaman } \\
\text { melalui } \\
\text { eksperimen }\end{array}$ & $\begin{array}{l}\text { Laju Alir }(v) \\
\text { Tekanan }(P) \\
\text { Luas } \\
\text { Penampang } \\
(A)\end{array}$ \\
\hline 2 & $\begin{array}{l}\text { D3 Teknik } \\
\text { Mesin }\end{array}$ & $\begin{array}{l}\text { Mekanika } \\
\text { Fluida }\end{array}$ & $\begin{array}{l}\text { Karburator adalah alat dalam mesin } \\
\text { kendaraan yang berfungsi untuk } \\
\text { menghasilkan campuran bahan bakar } \\
\text { dengan udara lalu campuran ini } \\
\text { dimasukkan ke dalam silinder mesin } \\
\text { untuk pembakaran. Prinsip kerja } \\
\text { Karbulator adalah seperti penampang } \\
\text { pada bagian atas jet menyempit, } \\
\text { sehingga udara yang mengalir pada } \\
\text { bagian ini bergerak dengan kelajuan } \\
\text { yang tinggi, sesuai dengan Hukum } \\
\text { Bernoulli, tekanan pada bagian ini } \\
\text { rendah. Tekanan di dalam tangki bensin } \\
\text { sama dengan tekanan atmosfer. } \\
\text { Tekanan atmosfer memaksa bahan } \\
\text { bakar (bensin atau solar) tersembur } \\
\text { keluar melalui jet, sehingga bahan } \\
\text { bakar bercampur dengan udara sebelum } \\
\text { memasuki silinder mesin. }\end{array}$ & $\begin{array}{l}\text { Tidak } \\
\text { membutuhkan } \\
\text { Pendalaman } \\
\text { melalui } \\
\text { eksperimen }\end{array}$ & \\
\hline 3 & $\begin{array}{l}\text { D3 Teknik } \\
\text { Aeronautika }\end{array}$ & $\begin{array}{l}\text { Mekanika } \\
\text { fluida }\end{array}$ & $\begin{array}{l}\text { Penerapan Hukum Bernoulli berkaitan } \\
\text { erat dengan aliran fluida, gaya angkat } \\
\text { pesawat, desain sayap pesawat terbang, } \\
\text { dan juga dalam proses aliran fluida } \\
\text { pada mesin-mesin pesawat terbang. }\end{array}$ & $\begin{array}{l}\text { Tidak } \\
\text { membutuhkan } \\
\text { pendalaman } \\
\text { melalui } \\
\text { eksperimen }\end{array}$ & \\
\hline 4 & $\begin{array}{l}\text { D3 Teknik } \\
\text { Kimia } \\
\text { D4 Teknik } \\
\text { Kimia Produksi } \\
\text { Bersih }\end{array}$ & $\begin{array}{l}\text { Mekanika } \\
\text { fluida } \\
\text { Satuan } \\
\text { proses }\end{array}$ & $\begin{array}{l}\text { Penerapan Hukum Bernaolli pada } \\
\text { pengukuran besaran-besaran fisis pada } \\
\text { aliran fluida dalam pipa aliran serta } \\
\text { koreksinya terhadap gesekan fluida } \\
\text { maupun dalam pengukuran pada } \\
\text { instalasi pengolahan air minum atau } \\
\text { limbah. }\end{array}$ & $\begin{array}{l}\text { Membutuhkan } \\
\text { pendalaman } \\
\text { melalui } \\
\text { eksperimen }\end{array}$ & $\begin{array}{l}\text { Laju alir }(v) \\
\text { Tekanan }(P) \\
\text { Luas } \\
\text { penampang } \\
(A) \\
\text { Massa jenis } \\
\text { fluida }(\rho) \\
\end{array}$ \\
\hline \multicolumn{6}{|c|}{$\begin{array}{l}\text { Berdasarkan Tabel } 2 \text { di atas, 67\% narasumber } \\
\text { berpendapat perlunya pendalaman konsep Hukum } \\
\text { Bernoulli melalui eksperimen. Selain untuk } \\
\text { mendukung pemahaman dasar mahasiswa dalam mata } \\
\text { kuliah prodi terkait juga memberi pemahaman dasar } \\
\text { mengenai aplikasi Hukum Bernolli terkait kekhasan } \\
\text { prodi masing-masing. Hal lain yang mendukung } \\
\text { pentingnya konsep ini adalah hasil kajian silabus } \\
\text { MKK prodi seperti ditunjukkan oleh Tabel 2 diatas. } \\
\text { Tampak 100\% prodi subjek penelitian memasukkan }\end{array}$} \\
\hline
\end{tabular}
walaupun prodi Teknik Kimia Produksi Bersih DIV Manometer 


\section{Desain Eksperimen Hukum Bernoulli}

Pendekatan ideal, syarat, dan batas keberlakuan Hukum Bernoulli dapat dijadikan dasar desain eksperimen. Dari Tabel 2, tampak besaran-besaran fisis dalam eksperimen meliputi laju alir fluida $(v)$, tekanan udara $(P)$, luas penampang pipa $(A)$ dan massa jenis fluida $(\rho)$.

Gambar 1 menunjukkan penampang venturimeter dengan manometer beserta besaran-besaran fisis yang dapat diukur atau dihitung dengan persamaan yang telah diturunkan dari persamaan Bernoulli [4] sebagai berikut:

$$
v_{1}=A_{2} \sqrt{\frac{2\left(\rho_{L}-\rho_{F}\right) g \Delta h}{\rho_{F}\left(A_{1}^{2}-A_{2}^{2}\right)}}
$$

dan

$$
v_{2}=A_{1} \sqrt{\frac{2\left(\rho_{L}-\rho_{F}\right) g \Delta h}{\rho_{F}\left(A_{1}^{2}-A_{2}^{2}\right)}}
$$

Dengan keterangan :

$v_{1}$ : kecepatan aliran pada permukaan $1(\mathrm{~m} / \mathrm{s})$

$v_{2}:$ kecepatan aliran pada permukaan $2(\mathrm{~m} / \mathrm{s})$

$A_{1}$ : luas penampang $1\left(\mathrm{~m}^{2}\right)$

$A_{2}$ : luas penampang $2\left(\mathrm{~m}^{2}\right)$

$\Delta h$ : beda tinggi muka fluida pada manometer $(\mathrm{m})$

$\rho_{F}$ : massa jenis fluida pada venturimeter $\left(\mathrm{kg} / \mathrm{m}^{3}\right)$

$\rho_{L}$ : massa jenis fluida pada manometer $\left(\mathrm{kg} / \mathrm{m}^{3}\right)$

$g \quad$ : percepatan gravitasi $\left(\mathrm{m} / \mathrm{s}^{2}\right)$

Eksperimen dapat dilakukan dengan pengukuran besaran terikat dan memvariasikan besaran-besaran sebagai variabel bebas, seperti ditunjukkan oleh Tabel 3.

\begin{tabular}{|c|c|c|c|c|c|c|}
\hline \multirow{3}{*}{ No. } & \multirow{3}{*}{$\begin{array}{c}A_{1}=\ldots \ldots \ldots \ldots \ldots \ldots . . . . . . . . . . . . \mathrm{m}^{2} \\
\text { Beda ketinggian pada } \\
\text { Manometer } \Delta h(\mathrm{~m})\end{array}$} & \multirow{3}{*}{ 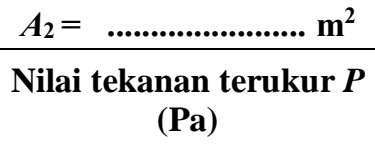 } & \multicolumn{4}{|c|}{ 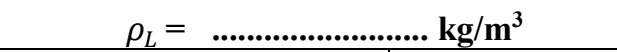 } \\
\hline & & & \multicolumn{2}{|c|}{ Kecepatan alir fluida (v) } & \multicolumn{2}{|c|}{$v^{2}$} \\
\hline & & & $v_{1}(\mathrm{~m} / \mathrm{s})$ & $v_{2}(\mathrm{~m} / \mathbf{s})$ & $v_{1}^{2}$ & $v_{2}^{2}$ \\
\hline \multicolumn{7}{|l|}{1.} \\
\hline \multicolumn{7}{|l|}{2.} \\
\hline \multicolumn{7}{|l|}{3.} \\
\hline \multicolumn{7}{|l|}{4.} \\
\hline \multicolumn{7}{|l|}{5.} \\
\hline \multicolumn{7}{|l|}{6.} \\
\hline 7. & & & & & & \\
\hline
\end{tabular}

Tabel 3. Data percobaan pada eksperimen Hukum Bernoulli

Dari data pada Tabel 3 di atas, dapat dibuat grafik linear antara beda ketinggian pada manometer $(\Delta h)$ sebagai sumbu $\mathrm{x}$ dan kuadrat kecepatan $\left(v_{1}\right.$ atau $\left.v_{2}\right)$ terukur sebagai sumbu y. Pengambilan data diulang minimal tujuh kali data. Dengan menggunakan metode kudrat terkecil pada persamaan (1) $\quad v_{1}^{2}=$ $A_{2}^{2} \frac{2\left(\rho_{L}-\rho_{F}\right) g}{\rho_{F}\left(A_{1}^{2}-A_{2}^{2}\right)} \Delta h$ yang didekati sebagai persamaan linier $Y=A+B x$, maka akan dapat dihitung massa jenis fluida yang mengalir $(\rho)$. Kemiringan grafik (gradien) memenuhi:

$$
B=A_{2}^{2} \frac{2\left(\rho_{L}-\rho_{F}\right) g}{\rho_{F}\left(A_{1}^{2}-A_{2}^{2}\right)}
$$

Percobaan pada Tabel 3 dapat diulang dengan memvariasikan luas penampang $A_{1}$ dan luas penampang $A_{2}$.

\section{Simpulan}

Berdasarkan studi dokumen silabus MKDK Fisika Terapan prodi-prodi Jurusan Rekayasa, hampir 50\% prodi memasuk Konsep Hukum Bernoulli sebagai salah satu pokok bahasan MKDK Fisika Terapan. Di sisi lain, data hasil kuesioner dan wawancara menunjukkan bahwa keseluruhan narasumber, yaitu 6 dosen MKK Prodi DIII dan Prodi DIV di Jurusan Rekayasa POLBAN terkait, berpendapat bahwa konsep Hukum Bernoulli perlu diajarkan dalam MKDK Fisika Terapan. Konsep ini sangat penting untuk menunjang beberapa mata kuliah yang ada di prodi.

Sebanyak 67\% narasumber berpendapat perlu adanya pendalaman konsep Hukum Bernoulli melalui eksperimen dan $100 \%$ prodi subjek penelitian memasukkan konsep Hukum Bernoulli dalam silabus salah satu MKK prodinya. Selain untuk mendukung pemahaman dasar mahasiswa dalam mata kuliah prodi yang terkait, juga memberikan pemahaman dasar prihal aplikasi Hukum Bernolli terkait kekhasan prodi masing-masing.

Berdasarkan kebutuhan aplikasi di masing-masing prodi, yang dijadikan dasar desain eksperimen adalah pendekatan ideal, syarat, dan batas keberlakuan Hukum Bernoulli. 


\section{Ucapan Terimakasih}

Terimakasih kepada teman-teman sejawat yaitu para dosen pengampu mata kuliah prodi terkait di Jurusan Teknik Mesin, Teknik Konversi Energi dan Teknik Kimia POLBAN yang telah membantu melalui diskusi sehingga kegiatan penelitian ini bisa berlangsung.

\section{Daftar Acuan}

[1] Sudirman. Ilmu Pendidikan. Bandung, Remaja Rosda Karya (1991).

[2] Ali, M. Guru dalam Proses Belajar Mengajar. Bandung, Sinar Baru Algesindo (2000).

[3] Sudjana, N. Dasar-Dasar Proses Belajar Mengajar. Jakarta, Sinar Baru Algesindo (2000).

[4] Giancoli, D.C. Fisika Jilid I (Terjemahan), Jakarta, Erlangga (2001). 